九州大学学術情報リポジトリ

Kyushu University Institutional Repository

\title{
A study on Marine Algal Succession and Community in Pyramid-shaped Artificial Reef
}

\section{CHOI, Chang Geun}

Department of Ecological Engineering, Pukyong National University

JUNG, Seung Wook

Department of Ecological Engineering, Pukyong National University

AHN, Jung Kwan

Korea National Park Service, National Park Research Institute

SHIMASAKI, Yohe i

Laboratory of Marine Environmental Science, Department of Bioresource Sciences, Faculty of Agriculture, Kyushu University

他

https://doi.org/10.5109/2232291

出版情報：九州大学大学院農学研究院紀要. 64 (1)，pp.95-99，2019-02-28. Faculty of Agriculture， Kyushu University

バージョン :

権利関係 : 


\title{
A study on Marine Algal Succession and Community in Pyramid-shaped Artificial Reef
}

\author{
Chang Geun CHOI ${ }^{1}$, Seung Wook JUNG ${ }^{1}$, Jung Kwan AHN ${ }^{2}$, Yohei SHIMASAKI \\ and Ik Joon KANG ${ }^{3 *}$
}

\author{
Laboratory of Marine Environmental Science, Department of Bioresource Sciences, \\ Faculty of Agriculture, Kyushu University, Fukuoka 819-0395, Japan \\ (Received October 31, 2018 and accepted November 12, 2018)
}

\begin{abstract}
We propose a marine ecosystem restoration means to build marine ecosystems and restore marine forests by introducing ecological engineering concepts to oceans that have lost habitats and include dysfunctional marine ecosystems using pyramid-shaped artificial reefs during 2016 to 2017 at Mundong, Busan, Korea. The marine algal succession in the artificial reefs was as follows: in January of 2016, two months after the reef installment, only Ulva spp. and non-geniculated coralline algae were found. Ten months after installment, non-geniculated coralline algae were dominant; however, perennial Ecklonia cava continued to grow robustly. During the 2 years of monitoring, Ecklonia cava and Grateloupia elliptica were the dominant species growing on the artificial reefs. During the earlier stages post-installment, short-lived annual marine algae attached and grew on the reefs; however, as time progressed, the algal succession pattern changed to perennial marine algal dominance. In this study with artificial reefs, from the early stages post reef installment, various marine algal succession were observed in stages, and after normal structured communities were formed, a large perennial brown algae colony attached to the reef and formed a stable community. When installing artificial reef in new regions for ecological restoration, higher success rates will be observed if the surrounding vegetation is considered and the installation timed to when the large marine algae release their spores. Therefore, the timing of artificial reef installment should be carefully considered.
\end{abstract}

Key words: Ecosystem restoration, Marine forest, Ecological engineering, Succession

\section{INTRODUCTION}

Generally, marine forests are locations in the ocean where marine algae and eelgrass are abundant in large areas, similar to the forests on land. However, during the high economic growth period after the 1960's, land was reclaimed from coastal waters, concrete buildings were built near the coast line, and industrial water waste coming from the coastal industry caused water pollution; these factors collectively increased environmental pollution, which rapidly decreased the naturally formed marine forests. As a result, the total marine forest area has decreased by about $40 \%$ in the three decades since the 1980's (Serisawa et al. 1998; Cho et al. 2007).

Recently, barren ground formation in many areas has been reported to reduce marine forests. Research on the effects of barren ground formation was initiated on Jeju Island, and more research is continuing on the east coast and south coastal waters of Korea, while barren grounds are gradually expanding in the eastern coastal waters (MOMAF, 2002; Choi et al. 2006b; Sohn et al. 2007). Therefore, to restore the marine ecosystem and marine resources, artificial marine forests are necessary, and various studies on marine forest formation are being conducted by phycologists and fishery scientists (Serisawa and Ohno, 1995a, b; Choi et al. 2006a). The

\footnotetext{
1 Department of Ecological Engineering, Pukyong National University, Busan 48513, Korea

2 Korea National Park Service, National Park Research Institute, Yeosu 59723, Korea

3 School of Interdisciplinary Science and Innovation, Kyushu University, Fukuoka 819-0395, Japan

* Corresponding author (E-mail: ij-kang@kyoso.kyushu-u.ac.jp)
}

installation of artificial reef is one method of artificial marine forest formation, and research on the marine algal succession process from the point of artificial reef placement to marine forest formation is very important (Serisawa and Ohno, 1995b; Choi, 2001). The usage of artificial reef in coastal waters for artificial marine forest formation, increase in marine resources, expansion of habitats, microorganism growth area formation, etc., has developed into an extremely important and generalized method for marine ecosystem restoration. Marine ecosystem formation using artificial reefs increases the number of marine products and marine resource organisms, and thereby naturally increases the amount of resources and yield (Choi et al. 2002, 2006a).

Researches of marine forest expansion and of increasing marine resource utilizing artificial reefs in Korea started from 1971 in all coastal areas of the country to create coastal resources, improve the environment for low-production fisheries, and to create marine ecosystems. However the materials and shapes of the artificial reefs have been limited and the majority of the installations have been concrete reefs. Recently, materials such as steel or ceramic has been used for artificial reefs to target diverse organisms such as fish, benthos, marine algae, etc.; however, diversity in the usage and materials of the artificial reef needs to be further developed (Cho et al. 2007; Choi, 2001).

The substrate is an important aspect of benthos distribution, and which substrate the organisms adjust to determines how each physiologically adjusts to the changes in habitat (Nybakken, 1982). However in a natural environment, there are many limitations and difficulties in determining the characteristics of the sub- 
strate-based distribution pattern of the benthos, because it is difficult for the researcher to control the date of substrate formation, location, gradient, direction, environmental factors, etc. Therefore, algal succession and distribution analysis with artificial substrates offers diverse usefulness on the ecological study of benthos (Osman, 1982; Kim, 1987).

In this study, we propose a marine ecosystem restoration means to build marine ecosystems and restore marine forests, etc., by introducing ecological engineering concepts to oceans that have lost habitats and include dysfunctional marine ecosystems due to various causes, such as the formation of barren grounds, increase in water temperatures, and marine pollution. Considering its potential for future applications in ecosystem restoration, a pyramid-shaped artificial reef was used, since the structure seemed more habitable for marine algae and benthos. This study was conducted to elucidate the characteristics related to marine algae attachment, stage-based pattern of succession, and the possibility to create marine forests.

\section{MATERIALS AND METHODS}

\section{Marine environment}

An artificial reef was installed at Mundong-ri, Gijang-gun, Busan in November 2015. To determine the marine environment characteristics, eight quarterly investigations were carried out during 2016 and 2017. Water temperature, salinity, DO, $\mathrm{pH}$, transparency were measured at the top of the artificial reef with YSI$6600 \mathrm{~V} 2$ and Secchi disc $(\phi 30 \mathrm{~cm})$.

\section{Diving investigation}

Following placement of the pyramid-shaped artificial reef, eight quarterly SCUBA diving investigations were performed in 2016 and 2017 to determine which organisms were living attached to the surface of the reef. Quantitative analysis was performed with samples collected from $25 \times 25 \mathrm{~cm}$ or $50 \times 50 \mathrm{~cm}$ quadrats on the reef, and all attached organisms were collected after underwater photographing. Separately, organisms not found in the sampling quadrats were photographed and sampled, and were included in the species list for the qualitative analysis of organisms living on or near the reef.

\section{Analysis of attached organisms}

The collected marine algae samples were thoroughly washed with fresh water to remove contaminants, and they were categorized based on the taxonomic group and species classification; species identity was determined either by eye, dissection microscope (Nikon SMZ745T), or optical microscope (Olympus BX41). We referred to recent publications for the observed marine algae species list and scientific names (Kang, 1968; Kim et al. 2013; Lee and Kang, 2002). The biomass of each sample was obtained by measuring the dry weight after species separation and dehydration in a dryer set to $105^{\circ} \mathrm{C}$ for $24-48 \mathrm{~h}$ and was converted to biomass per unit area $\left(\mathrm{g} / \mathrm{m}^{2}\right)$.

To measure the ecological index of the algal community in the study sites, the richness index, evenness index, and diversity index were calculated based on the species formation and biomass data, and cluster analysis was performed with PRIMER version 5.0.

\section{RESULTS AND DISCUSSION}

The marine environment data measured during the research period is shown in Table 1 . The water temperature was $7.31-24.93^{\circ} \mathrm{C}$ at the surface and $7.09-24.56^{\circ} \mathrm{C}$ at the bottom, and seasonal temperatures were observed; the temperature was highest during the summer season and lowest in the winter season. Salinity was 31.1635.41 PSU at the surface and 32.07-35.40 PSU at the bottom; DO was $1.77-6.77 \mathrm{mg} / \mathrm{L}$ at the surface and 1.54 $6.84 \mathrm{mg} / \mathrm{L}$ at the bottom. pH was $6.99-8.38$ at the surface and $7.10-8.37$ at the bottom, and transparency was in the range of $1.7-5.0 \mathrm{~m}$.

The marine algal succession in the pyramid-shaped artificial reefs was as follows: in January of 2016, two months after the reef installment, only Ulva spp. and non-geniculated coralline algae were found. In March, the attachment and growth of Ulva spp., Papenfussiella kuromo, and the blade of Ecklonia cava on the reef were growth. Ecklonia cava was the dominant species, and the average dry weight was $3.32 \mathrm{~g} / \mathrm{m}^{2}$. Eight months after reef installment, not only Ulva australis and Ecklonia cava, but also various red algae such as

Table 1. Marine environment around pyramid-shaped artificial reef

\begin{tabular}{cccccccccc}
\hline & & $1^{\text {st }}$ & $2^{\text {nd }}$ & $3^{\text {rd }}$ & $4^{\text {th }}$ & $5^{\text {th }}$ & $6^{\text {th }}$ & $7^{\text {th }}$ & $8^{\text {th }}$ \\
\hline \multirow{2}{*}{ Temp. $\left({ }^{\circ} \mathrm{C}\right)$} & Surface & 8.52 & 7.31 & 15.38 & 13.71 & 9.15 & 13.42 & 17.25 & 24.93 \\
& Bottom & 8.02 & 7.09 & 12.43 & 13.63 & 8.12 & 13.98 & 15.68 & 24.56 \\
\multirow{2}{*}{ Salinity (PSU) } & Surface & 33.80 & 33.03 & 32.36 & 34.06 & 35.41 & 31.16 & 34.37 & 32.16 \\
& Bottom & 33.80 & 33.10 & 33.26 & 34.16 & 35.40 & 32.07 & 35.23 & 32.30 \\
\multirow{2}{*}{ DO (mg/L) } & Surface & 6.77 & 6.70 & 1.77 & 3.50 & 4.79 & 4.53 & 5.48 & 4.79 \\
& Bottom & 6.84 & 6.70 & 1.54 & 3.96 & 5.69 & 4.65 & 5.65 & 4.53 \\
pH & Surface & 7.49 & 7.07 & 7.97 & 7.60 & 6.99 & 8.18 & 7.92 & 8.38 \\
\multicolumn{2}{c}{ Transparency (m) } & 7.53 & 7.10 & 8.04 & 7.84 & 7.19 & 8.25 & 8.17 & 8.37 \\
\hline
\end{tabular}


Pachymeniopsis elliptica, Chondrus ocellatus, Lomentaria catenata, Chondracanthus intermedius, and Gelidium elegans were growing on the reef. Ten months after installment, non-geniculated coralline algae were dominant; however, perennial Ecklonia cava continued to grow robustly, with an average dry weight of $8.42 \mathrm{~g} / \mathrm{m}^{2}, 77.6 \%$ of the total marine algae. At 14 months post-installment, Ecklonia cava was the dominant species, and red algae such as Chondrus ocellatus and Plocamium telfairiae coexisted; in subsequent investigations, red algae such as Pachymeniopsis elliptica, Corallina pilulifera, and Lomentaria catenata were dominant. The Ecklonia cava length was approximately 30-50 cm, showing continuous development compared to earlier stages of growth. During the 2 years of monitoring, Ecklonia cava and Pachymeniopsis elliptica were the dominant species growing on the artificial reefs, and marine algae such as Chondrus ocellatus, Chondracanthus tenellus, Pterocladiella capillacea, Rhodymenia intricata, and Corallina pilulifera were frequently observed. During the earlier stages post-installment, short-lived annual marine algae attached and grew on the reefs; however, as time progressed, the algal succession pattern changed to perennial marine algal dominance (Table 2).

It is known that during the initial stages of marine algal succession on artificial reef shortly after installment, short-lived pioneer species are dominant; consistent with this, our research showed Ulva spp. as the early settler on the reef surface 2 months after reef installment (Serisawa et al. 1998). Kim (1987) reported that pioneer algae (the first algae that adheres to the new artificial surface) mostly consisted of spherical bluegreen algae, diatom, filamentous green algae, or crustose coralline algae. Our results were consistent with these findings.

Thereafter, during the monitoring at 8 months after installment, the species that appeared changed from pioneer algae to Ecklonia cava, Pachymeniopsis elliptica, Gelidium elegans, etc. These marine algae were stably maintained without significant changes even after 2 years, showing a stable succession pattern of the dominating perennial brown algae Ecklonia cava. Corallina pilulifera, geniculated coralline algae, and non-geniculated coralline algae also consistently grew on the reef surface.

Choi et al. (2006a) separated the succession process into three stages (early stage, second stage, and climax stage), and reported that marine algal flora gradually changes from the short-lived Ulva intestinalis and Colpomenia sinuosa dominating early succession stage. They reported that the artificial reef showed stable succession patterns with perennial large brown algae dominance 24 months after entering the second stage; in our research, we observed the same pattern of initial growth of short-lived marine algae, later leading to perennial algae succession. Niell (1979) reported into three phases the process of marine algae community formation after attaching to temperate seas substrates: colonization phase, channeling succession phase, and normal structured communities, and the marine algal succession pattern we observed two years after reef installation was in the normal structured communities phase.

So far, research elucidating the marine algae ecological characteristics on the artificial reefs installed in our seas, such as determining the marine algal community succession pattern and community structures, has been insufficient (Kim and Park, 1997). However, since artificial reef is frequently installed to protect marine resources, increase the number of fishes caught, and build artificial marine forests, the results obtained from these studies have great importance as useful data for diverse fields. Therefore, when artificial reef is installed and related studies are conducted in various seas, studies of the marine algal succession pattern and community analysis should also be conducted.

The marine algae that appeared in the artificial reefs during our study comprised a total of 83 species; 9 Chlorophyta, 4 Phaeophyta, and 70 Rhodophyta were observed, and red algae comprised $84.3 \%$ of the total species observed. The average dry weight of the investigational area was $140.10 \mathrm{~g} / \mathrm{m}^{2}$; green algae was $0.48 \mathrm{~g} / \mathrm{m}^{2}$, brown algae was $88.97 \mathrm{~g} / \mathrm{m}^{2}$, and red algae was $50.66 \mathrm{~g} / \mathrm{m}^{2}$. Brown algae had the highest percentage, accounting for $63.5 \%$ of the total dry weight (Table 3 , Figs. 1, 2).

The number of observed species per investigation period is as follows; 3 Chlorophyta, 2 Phaeophyta, and 34 Rhodophyta (a total of 39 species) were observed in January to May of 2017, which was the highest number

Table 2. Percentage (\%) of dry weight of dominant marine algal species during study period

\begin{tabular}{|c|c|c|c|c|c|c|c|}
\hline Species & $2^{\text {nd }}$ & $3^{\text {rd }}$ & $4^{\text {th }}$ & $5^{\text {th }}$ & $6^{\text {th }}$ & $7^{\text {th }}$ & $8^{\text {th }}$ \\
\hline Ulva spp. & 15.9 & & & & & & \\
\hline Ecklonia cava & 62.1 & 79.7 & 77.6 & 85.7 & 61.4 & 44.5 & 78.7 \\
\hline Papenfussiella kuromo & 21.3 & & & & & & \\
\hline Pachymeniopsis elliptica & & 18.1 & 22.2 & & 15.5 & 17.5 & 5.2 \\
\hline Grateloupia cornea & & & 0.2 & & & & \\
\hline Grateloupia spp. & & & & 4.5 & & & \\
\hline Chondrus ocellatus & & 1.0 & & & & & 3.5 \\
\hline Chondrus spp. & & & & 3.8 & & & \\
\hline Corallina pilulifera & & & & & 6.2 & 11.8 & \\
\hline
\end{tabular}


Table 3. Number of marine algal species and dry weight in pyramid-shaped artificial reef

\begin{tabular}{ccccc}
\hline Division & No. species & Ratio (\%) & $\begin{array}{c}\text { Mean DW } \\
\left(\mathrm{g} / \mathrm{m}^{2}\right)\end{array}$ & Ratio (\%) \\
\hline Chlorophyta & 9 & 10.8 & 0.48 & 0.3 \\
\hline Phaeophyta & 4 & 4.8 & 88.97 & 63.5 \\
\hline Rhodophyta & 70 & 84.3 & 50.66 & 36.2 \\
\hline Total & 83 & 100.0 & 140.10 & 100.0
\end{tabular}

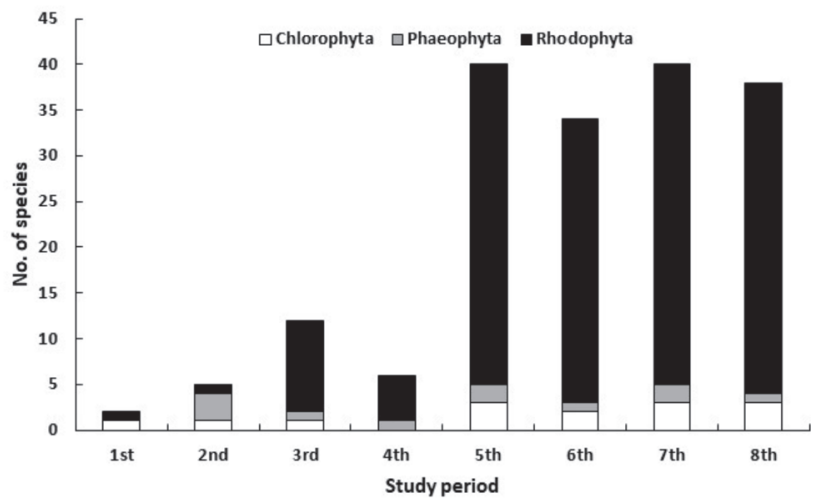

Fig. 1. Number of marine algal species in pyramid-shaped artificial reef.

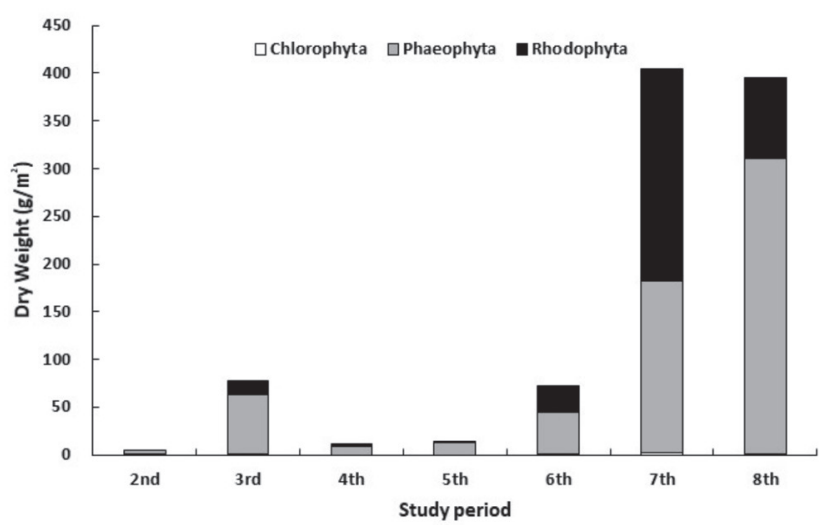

Fig. 2. Dry weight of marine algal species in pyramid-shaped artificial reef.

of species observed during the investigational period. During the early stages after reef installment, in March of 2016, the least number of species was observed, which consisted of 1 Chlorophyta, 3 Phaeophyta, and 1 Rhodophyta. The dry weight of the marine algae attached to the reef was highest in the May 2017 investigation, reaching an average of $404.87 \mathrm{~g} / \mathrm{m}^{2}$, and lowest in March of 2016, which was also when the lowest number of species was observed, with an average of $5.35 \mathrm{~g} / \mathrm{m}^{2}$.

The dominant species that was observed on the artificial reef, determined by the dry weight, was the brown algae Ecklonia cava, which had an average dry weight of $88.80 \mathrm{~g} / \mathrm{m}^{2}$, comprising $63.4 \%$ of the total dry weight. Red algae Pachymeniopsis elliptica and Corallina pilulifera were also dominant, with average dry weights of $17.00 \mathrm{~g} / \mathrm{m}^{2}(12.1 \%)$ and $9.20 \mathrm{~g} / \mathrm{m}^{2}$ (6.6\%), respectively.
Ecklonia cava growing on the surface of the artificial reef is greatly affected by the ocean and tidal current, and the density of Ecklonia cava is highest where the tidal current forms a whirlpool on the reef surface (Cho et al. 2007). Depending on the artificial reef structure, the attached Ecklonia cava density can differ by up to 8-fold. Foster (1975) reported that the edge effect increases the settlement of marine algae spores, and Choi et al. (2002) stated that blade attachment is easier on the edge of the artificial reef where the whirlpool forms. The dominant growth of Ecklonia cava on the reef surface observed in our study suggests that either the edge effect or whirlpool effect had an influence on the growth of Ecklonia cava. Furthermore, the Ecklonia cava population attached to the artificial reef stably developed a community, and the annual and perennial population co-existed to form a community of mixed life-spans.

Kim and Park (1997) speculated that the community formed on artificial substrates in the intertidal zone near the one-year period forms a stable structure. However in our study, the Ecklonia cava attached to the artificial reef within 4 months of reef installment, and stably developed thereafter. The shortened time required for stable growth of the Ecklonia cava and the formation of an algal community suggests that the surrounding marine environment was optimal for marine algae attachment and growth.

Kang et al. (2008) reported that Pachymeniopsis spp., Ulva australis, Ecklonia cava, etc. are widely distributed in Ilgwang bay, which is near our research area, and that those species dominate in autumn and winter. The dominating species of our studies were similar, and we speculate that the new substrate in the artificial reef was suitable for marine algae development. The composition and biomass of the coastal marine species have been decreasing due to ocean pollution caused by recent increases in ocean temperatures, various marine pollution accidents, and increased usage of ocean space (Choi, 2007). The installation of artificial reefs that have wide applications as a new substrate can be offered as a solution to these problems.

The ecological indices at each peak period were as follows: richness index was 16.59, evenness was 0.34, and diversity was 1.49 (Table 4). During the investigational period, richness was highest in January of 2017 with a value of 14.34, and the lowest value (1.68) was reached in September of 2016. Evenness showed the highest value (0.59) in March of 2016, and the lowest was 0.18 , in January of 2017. Diversity was highest (1.88) in May of 2017, and the lowest was 0.55, in September of 2016.

Table 4. Ecological index of marine algal species in pyramidshaped artificial reef

\begin{tabular}{cccc}
\hline & Richness & Evenness & Diversity \\
\hline $\begin{array}{c}\text { Pyramid-shaped } \\
\text { artificial reef }\end{array}$ & 16.59 & 0.34 & 1.49 \\
\hline
\end{tabular}


Our ecological indices of the marine algae growing on the artificial reef surface were similar or slightly lower than the species diversity index of 1.2-3.0 calculated from the marine algal coverage in the nearby Ilgwang Bay (Kang et al. 2008). This difference is considered to be due to the environmental differences during the peak of each study. The severe changes in salinity and the soft bottom environment of the seas near Ilgwang Bay is thought to cause a greater deviation in the species diversity index, compared to the diversity index calculated from the artificial reef. Yoo (2003) suggested that to accurately determine the criteria for the maintenance of a stable community, substantial research on marine algae communities in different environments needs to be conducted, and that it is unreasonable to determine species diversity based on simple numerical values. Therefore, the diversity index calculated in this study, and the numbers calculated by prior studies conducted nearby, should only be compared to determine whether there was a significant difference.

In this study with artificial reefs, from the early stages post reef installment, various marine algal succession were observed in stages, and after normal structured communities were formed, a large perennial brown algae colony attached to the reef and formed a stable community. These results showed that, in the future, when artificial reef is installed in the sand substrate near bedrock, the possibility of expanding the artificial marine forest is very high. In addition, when installing artificial reef in new regions for ecological restoration, higher success rates will be observed if the surrounding vegetation is considered and the installation timed to when the large marine algae release their spores. Therefore, the timing of artificial reef installment should be carefully considered.

\section{AUTHOR CONTRIBUTIONS}

C. G. Choi, S. W. Jung, J. K. Ahn, and I. J. Kang designed this study and drafted the manuscript. C. G. Choi, and I. J. Kang conceived and designed the study, and also revised the manuscript. Y. Shimasaki supervised the work. All authors read and approved the final manuscript.

\section{ACKNOWLEDGMENTS}

This work was supported by a research grant of Pukyong National University (2017 year).

\section{REFERENCES}

Cho, S. H., C. G. Choi and J. H. Choa 2007 Restoration of the seaweed forest and algal succession on a porous type (shaped half saw teeth) artificial reef. J. Kor. Fish. Soc., 40: 220-225

Choi, C. G. 2001 Marine communities around the experimental artificial reefs. Ph. D. Thesis, Pukyong National University, Korea. pp.1-190

Choi, C. G. 2007 Algal flora and Ecklonia stolonifera Okamura (Laminariaceae) population of Youngdo in Busan, Korea. Algae, 22: 313-318

Choi, C. G., Y. Takeuchi, I. Terawaki, Y. Serisawa, M. Ohno and C. H. Sohn 2002 Ecology of seaweed beds on two types of artificial reef. J. Appl. Phycol., 14: 343-349

Choi, C. G., M. Ohno and C. H. Sohn 2006a Algal succession on different substrata covering the artificial iron reef at Ikata in Shikoku, Japan. Algae, 21: 305-310

Choi, C. G., S. N. Kwak and C. H. Sohn 2006b Community structure of subtidal marine algae at Uljin on the East coast of Korea. Algae, 21: 463-470

Foster, M. S. 1975 Regulation of algal community development in a Macrosystis pyrifera forest. Mar. Biol., 32: 331-342

Kang, J. W. 1968 Illustrated encyclopedia of fauna \& flora of Korea. Vol. 8. Marine algae. Ministry of Education, Seoul, pp.465

Kang, P. J., Y. S. Kim and K. W. Nam 2008 Flora and community structure of benthic marine algae in Ilkwang Bay, Korea. Algae, 23: $317-326$

Kim, Y. H. 1987 A study on colonization and succession of marine algae using an artificial substratum. The Kor. J. Phycol., 2 73-91

Kim, H. S., S. M. Boo, I. K. Lee and C. H. Sohn 2013 National List of Species of Korea [Marine Algae]. National Institute of Biological Resources, Incheon, pp.336

Kim, Y. H. and S. H. Park 1997 Succession pattern of intertidal benthic algal communities in Cheju island. Algae, 12: 23-30

Lee, Y. P. and S. Y. Kang 2002 A Catalogue of the Seaweeds in Korea. Cheju National University Press, Cheju, pp.662

MOMAF. 2002. Cause of phenomena of getnokgum and the way to control it. Ministry of Maritime Affairs \& Fisheries, Korea, pp.263

Niell, F. X. 1979 Structure and succession in rocky algal communities of a temperate intertidal system. J. Exp. Mar. Biol. Ecol., 36: 185-200

Nybakken, J. W. 1982 Marine Biology: An ecological approach. Harper \& Row, publ., N.Y., pp.446

Osman, R. W. 1982. Artificial substrates, J. Cairns, Jr. (ed.). Ann Arbor Publ., MI, pp.71-114

Serisawa, Y., S. Taino, M. Ohno and Y. Aruga 1998 Succession of seaweeds on experimental plates immerged during different seasons in Tosa Bay, Japan. Bot. Mar., 41: 321-328

Serisawa, Y. and M. Ohno 1995a Succession of seaweed communities on artificial reefs in the inlet of Tosa Bay, Japan. Suisanzoshoku, 43: 437-443

Serisawa, Y. and M. Ohno 1995b Succession of seaweed communites on artificial reefs in Tei, Tosa Bay, Japan. Nippon Suisan Gakkaishi, 61: 854-859

Sohn, C. H., C. G. Choi and H. G. Kim 2007 Algal communities and useful seaweed distribution at Gangnung and its vicinity in East coast of Korea. Algae, 22: 45-52

Yoo, J. S. 2003 Dynamics of marine benthic commiunity in intertidal zone of Seoam, Busan. The Sea, 8: 420-425 